\title{
The Effect of Mordan on The Color Depth of Silk Fabric Dyed with Rambutan (Nephelium Lappaceum) Peel Extract
}

\author{
Wulansari Prasetyaningtyas ${ }^{1}$ Listiani $^{2}$ \\ \{wulan_sari@mail.unnes.ac.id\} \\ Department of Home Economic, Universitas Negeri Semarang, Indonesia ${ }^{12}$
}

\begin{abstract}
Synthetic dyes are usually carcinogenic; therefore, it is necessary to use alternative dyes to reduce the use of synthetic dyes, namely by using natural dyes. This study aims to determine 1) How depth the color of the silk cloth that is dyed using rambutan peel extract; 2) Is there an effect of using mordant on the color depth of the silk fabric that is dyed with rambutan peel extract. Extraction is done by boiling the rambutan peel for 1 hour. The dyeing of the silk cloth is carried out for 15 times. The test was carried out by testing the color depth on silk cloth that was dyed with rambutan peel extract with mordan alum, tunjung, and calium oxide. The results of the color depth test have the highest value on the use of tunjung mordan with an $\mathrm{R} \%$ value of 11.94 for very dark criteria, then followed by mordan alum with a value of 47.15 and the lowest value for using calium oxide mordan with a value of 58.87 for light criteria. The results of calculations using the Kruskal Wallis formula show that there is an effect of the use of mordant on the color of silk cloth dyed with rambutan peel extract as indicated by the value $\chi 2$ count $=9,359$ with a significance value of $0.025<0.05$.
\end{abstract}

Keywords: Mordan; Rambutan; rambutan peel extract;

\section{Introduction}

Indonesia is a country rich in plant diversity, many plant parts that can be used for coloring, for example: roots, stems, leaves, seeds and tree bark. The dyes contained in plants vary so that they produce various colors too. Before getting to know textile dyes from chemicals, textile coloring in Indonesia used natural dyes from animals and plants. Along with the development of science and technology, natural dyes began to be abandoned. The manufacture of dyes and the natural dyeing process that takes a long time, causes craftsmen to prefer to use dyes from chemicals or synthetic dyes. Synthetic dyes are considered more practical in their use compared to natural dyes. In addition, this synthetic dye is easy to obtain and produces a more varied color. But these synthetic dyes have the disadvantage of damaging the environment. The negative impact of using synthetic materials containing azo and used directly as dyes, especially in clothing, will trigger skin cancer (90\% damage epidermal cells) because of its carcinogenic properties [Kusumastuti \& Rodia S: 2016].

This condition resulted in in 1996 the Embassy of the Republic of Indonesia in the trade sector in Nederland, gave a warning about the dangers of synthetic dyes containing azo. As a result of this regulation, the trade route for synthetic dyes containing azo with all its products, especially those directly related to human skin, has been banned. Natural dyes could be 
obtained from plants, animals and minerals. In these materials there are pigments that produce color. Some of the many natural pigments found in plants include: chlorophyll, carotenoids, tannins and anthocyanium. Likewise with Laban leaves, these natural pigments are found in Laban leaves. Chlorophyll (chorophil) is a green color carrier substance in plants. Carotenoids are one of the natural pigments in the form of yellow to red dyes.

Usually bound with chlorophyll in chloroplasts from green leaves of plants. Some carotenoids consist only of hydrogen and carbohydrates, this sub group is called carotene. Other sub-groups are oxygenated carotenes (xanthophylls), carotenoid acids and esters (xanthophyll esters) [Saxena S \& Raja A: 2014]. Tannins are brown color-giving pigments that can be obtained from plants. Tannins are complex compounds, usually a mixture of polyphenols that do not crystallize. Anthocyanium (anthocyanin) is a water-soluble pigment that occurs naturally in various types of plants [Yazaki Y: 2015]. As the name implies, this pigment provides color to flowers, fruit and leaves of green plants, and has been widely used as a natural dye in various food products and in various other applications.

The diversity of natural resources that exist in Indonesia is very large, especially good plants that can be consumed by humans, for example fruits, vegetables or that cannot be consumed, such as grass and large trees. This condition requires us to be able to properly and maximally utilize the potential diversity of natural resources. Examples of plants that have been used as natural dyes include the leaves of the tilapia tree (Indigofera), bark of tingi tree (Ceriops candolleanaarn), tegeran wood (Cudraina javanensis), turmeric root (Curcuma), noni root (Morinda citrifelia), bark of soga jambal (Pelthophorum ferruginum), kesumba seeds (Bixa orelana), and guava leaves (Psidium guajava). Types of fruit plants that are often encountered in Indonesia include rambutan (Nephelium lappaceum). Rambutan (Nephelium lappaceum) is a native Indonesian fruit and greening plant, the tree species can reach 15-25 meters, has compound leaves, the flowers are panicle-shaped, the color of the fruit skin varies, including green, yellow, and red.

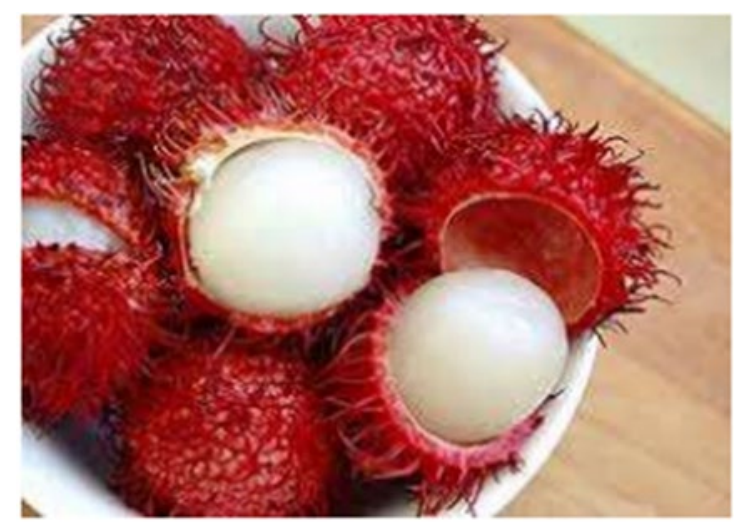

Fig 1. Rambutan (Nephelium lappaceum) fruits

Rambutan (Nephelium lappaceum) is a plant that has a lot of production in Indonesia and can be grown easily. Rambutan usually has two houses. Male plants can never bear fruit. Rambutan flowering is influenced by season or water availability. The three-month dry period stops vegetative growth and stimulates flower formation. In northern Sumatra, which does not know the dry season, rambutan can produce two harvests of fruit a year. In other places flowers usually appear after a dry period of three months in Java and Kalimantan, usually in 
October and November. Rambutan (Nephelium lappaceum) has the potential to be used as a natural dye by utilizing rambutan (Nephelium lappaceum) peel, as well as helping reduce the impact of environmental pollution due to the use of synthetic dyes. Anthocyanin provides color due to their long arrangement of conjugated double bonds, so they can absorb light in the visible range of light [Martin J, et. al: 2015]. Figure 1 shows pictures of rambutan (Nephelium lappaceum) fruits.

So far, rambutan peel is only used for syrup, hair dye, and biophori. There is no known type of rambutan peel used as dye for fabrics. This can be tested based on the theory of plant parts that can be used as natural dyes, namely fruit (skin, flesh and seeds), wood or bark, leaves and roots. There are several natural dyes contain other elements, such as nitrogen in indigo and magnesium in chlorophyll. Pigments are also present in animal cells. Biochemists have identified thousands of pigments that are from plants and the mechanisms and functions of these pigments [Saxena S \& Raja A: 2014]. Figure 2 shows pictures of rambutan (Nephelium lappaceum) peel.

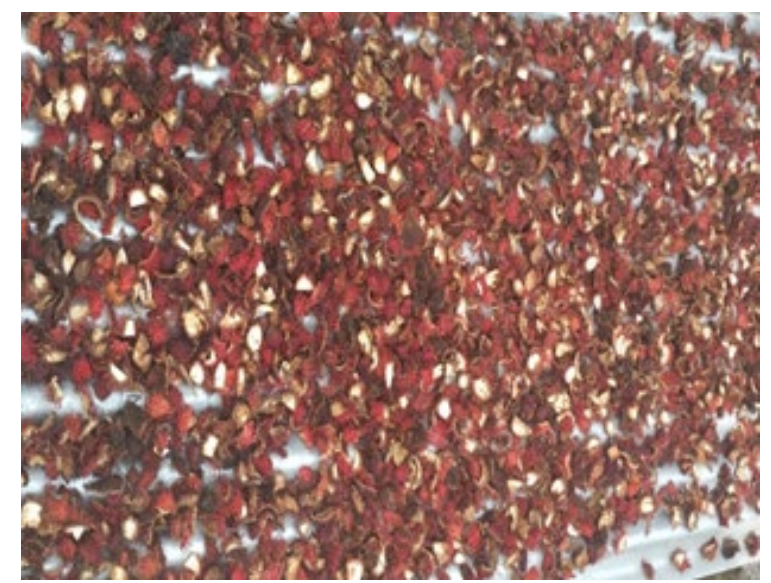

Fig 2. Rambutan (Nephelium lappaceum) peel

Silk is one of the oldest types of fiber in the world after linen and cotton. Silk fiber is a filament-shaped fiber obtained from a type of insect called Lepidoptera, the fiber is produced by the larvae of silk caterpillars when forming a group of caterpillars before becoming butterflies. The main species of silk caterpillars are bombyx mori. Mordant is a metal salt, such as aluminum, iron, tin, or chromium which functions to form a chemical bridge between natural dyes and fibers so that the affinity of natural dyes increases to fiber [Clark M: 2011]. Natural dyes are included in the mordant dye class, or in Javanese it is called "sarenan", its function is to generate colors in the direction of the color according to the type of composition and strengthen the color.

The substances used for sarenan include lime / limestone, alum, and tunjung water. Mordan is a substance that is used to increase the attractiveness of natural dyes to textiles and is useful for producing good evenness and color sharpness. The above understanding can be concluded that, mordant is metal salts that function to generate color on textiles and are useful for producing good color sharpness. Mordan used in this study is: 


\begin{abstract}
Alum
Alum is a double salt of aluminum sulfate sulfate, which is used to purify water or a mixture of AI2 (SO4)3 dyes. Alum is a dark white crystal, translucent, slightly sour in taste when licked, enhances color but can also be used as a water purifier.

\section{Calcium Oxide}

Calium oxide $(\mathrm{CaO})$, commonly known as lime or raw lime, is a chemical compound that is widely used. Quicklime is alkaline crystals, in the form of white to pale yellow / brown powder, odorless.

\section{Tunjung}

Tunjung (iron salt) is a chemical compound with the formula FeSO4. In ancient time, it was known as copperas \& vitrol which is green in color, heptahydrate which is blue - green in color.

The color excess in the dyeing process can be shown from the dark and light value of the dyeing color. The value of color saturation can be seen through the $\mathrm{R} \%$ (reflectance) test using a UV-VIS PC 2401 spectrophotometer which is then converted into a T\% (Transmittance) value, the color aging value determines the level of color difference or contrast from the lowest level to the highest level. The purpose of this study was to determine 1) how depth is the color of the silk cloth dyed using rambutan peel extract; 2) Is there an effect of using mordant on the color depth of the silk cloth dyed with rambutan peel extract.
\end{abstract}

\title{
2 Methodology
}

The tools used in the experiment, namely: (a) scales, (b) measuring cups, (c) stainless pans, (d) stirrers, (e) stoves, (f) pans, (g) basins, (h) scissors, (i) hanger, (j) spatula, (k) clamp, (l) timer. The materials used in the experiment, namely: (a) rambutan peel, (b) silk cloth, (c) filter gauze, (d) water, (e) alum, (f) calium oxide, (g) tunjung. Extraction is a term used for every activity, where the components of the material move into other liquids or solvents. The process of making a natural dye solution is the process of taking the pigments that are found in plants, whether found in leaves, stems, fruits, seeds, or roots. The exploratory process of taking natural dye pigments is called the extraction process. This extraction process is carried out by boiling the ingredients with water solvent. The part of the plant that is extracted is the part that is indicated as the strongest or has a lot of color pigment, for example, the leaves, stems, roots, fruit skin, seeds or fruit.

The rambutan peel extraction process is a process of taking dye from the rambutan peel which will be used to dye textile materials, namely as follows:

a. Cutting rambutan peel

b. Dry the cut rambutan peel

c. Weighing dry rambutan peel on a scale

d. Boiling with a ratio of dry rambutan peel and water, for $1 \mathrm{~kg}$ of rambutan peel used 10 liters of water and boiled for 1 hour or approximately the volume of water becomes half of the water medium used, which is 5 liters

e. Leave the solution for 30 minutes

f. Filtering until clean 
g. The extraction solution is ready to be used for immersion

The dyeing process is a process of giving color to fabric / textile material evenly with dyes. The dyeing process used is cold dyeing. The procedure for dyeing silk using rambutan peel extract is as follows:

a. The cloth samples are put into the extraction solution, let stand for 10 minutes for each sample and when dyed the cloth should not be turned backwards or too often so that the color can be evenly distributed.

b. The sample of the material is dried in the sun or aerated not to be exposed to direct sunlight

c. Repeat the above steps up to 15 times for each sample of each mordant used in immersion

d. After being dipped 15 times and the sample dry, the next step for the sample is the mordanting stage, where the sample is immersed in a mordant solution for 10 minutes and then aerated

Independent variables are variables that influence or cause changes or the emergence of the dependent variable. The independent variables in this study were mordant alum, calium oxide, and tunjung. While the dependent variable is a variable that is influenced or becomes a result of the independent variable. The dependent variable in this study is color depth. Descriptive analysis is used to describe or provide an overview of the object under study through sample or population data without analyzing and making general conclusions. Descriptive analysis in this study was used to see the results of the color depth of the silk cloth dyed using rambutan peel extract with variations of mordan alum, calium oxide and tunjung.

The data normality test is used to check whether the population is normally distributed or not. The data normality test in this study was seen from the Kolmogorof Smirnov value through the SPSS release 22 program. The decision-making method for the normality test is that if significant $>0.05$ then the data is normally distributed and if significant $<0.05$ then the data is not normally distributed" [6]. From the results of calculations using the SPSS release 22 program, it shows the Kolmogorov Smirnov value is 0,321 and the value in Asymp. Sig. (2 tailed) is $0.001<0.05$, so it can be concluded that the data on the color depth test are not normally distributed. The data homogeneity test (test of homogeneity of variances) is to find out whether the variants are the same or different.

The condition that applies is that the variants of the data group are the same" [Priyatno: 2010]. Through the homogeneity test of variance, this analysis can be seen from the value of Levene's test through the SPSS program. If the probability value $(\mathrm{P})$ is greater than the error level $(\alpha=0.05)$, the data is homogeneous. The results of calculating the homogeneity of the data using the SPSS program show that the levene's test value shows 0.616 and the asymp value. Sig. $0.00<0.05$, so it can be concluded that the data is not homogeneous.

The results of the prerequisite analysis showed that the data were not normally distributed and not homogeneous. Then the analytical test used to determine whether or not the effect of mordant on the color results of the dyed silk fabric using rambutan peel extract is the Kruskal Wallis test. 


\section{Result and Discussion}

Data collection of color depth is done by looking at the value of the color depth test (Transmittance $=\mathrm{T} \%$ ) with the ISR-2200 model Spectrophotometer (UV-PC), the color depth value determines the level of color difference or contrast from the lowest level to the highest level. The color depth data that has been obtained will then be analyzed descriptively. Table 1 shows the test results on the color depth of silk cloth with rambutan peel extract (Nephelium Lappaceum).

Table 1. Color Depth Test Results

\begin{tabular}{ll}
\hline Mordant & Mean $(\mathrm{R} \%)$ \\
\hline Alum & 47.15 \\
Calcium Oxide & 58.87 \\
Tunjung & 11.94 \\
\hline
\end{tabular}

The table above shows that the value of the color depth $\mathrm{R}(\%)$ of the color depth test from dyeing silk with rambutan peel (Nephelium Lappaceum) is shown with the smallest value which means the darkest color results, namely with mordan tunjung, produces a value of $11.94 \%$, which shows that from these results the silk fabric with mordan tunjung which produces the darkest color. Dyeing silk cloth with rambutan peel (Nephelium Lappaceum) using calium oxide mordant produces the lightest color seen from the R value (\%) of 58.87\%. The color of silk cloth using tunjung as mordant has the darkest / darkest color due to dyeing using tunjung mordan there is a reaction between tannins from rambutan peel extract and $\mathrm{Fe} 3+$ metal which produces complex salt (Ferro tanat). This complex salt is formed due to the coordination covalent bond between metal ions and non-metal ions [Taofik, et al: 2010]. The reaction between tannins and $\mathrm{Fe} 3+$ metal in silk dyeing using rambutan peel extract can be seen in the following figure:

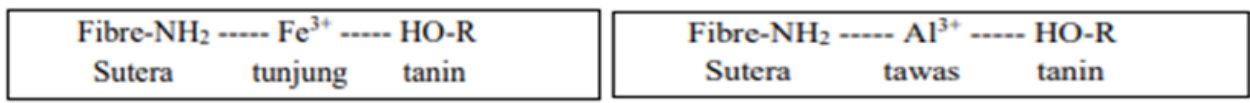

Fig 3. Reaction of tannins with $\mathrm{Fe} 3+$ and $\mathrm{Al} 3+$ metal from tunjung and alum on silk cloth dyed with rambutan peel extract.
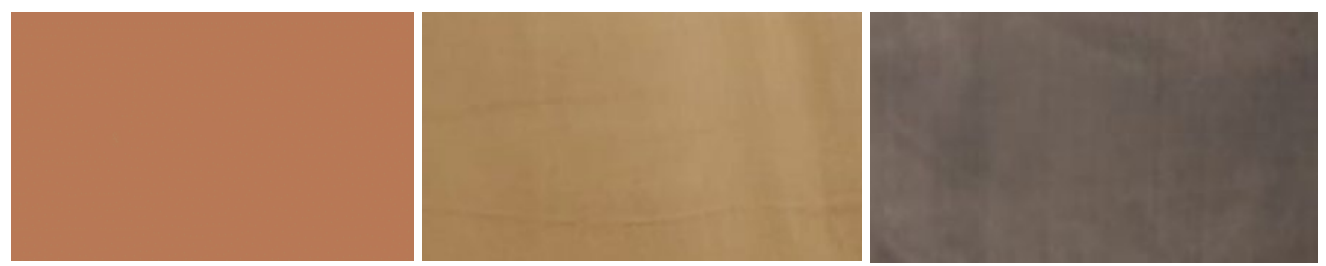

Fig 4. The result of staining silk with mordant alum, mordant calcium oxide, and mordant tunjung

The effect of mordant use on the color depth of the silk cloth dyed using the extract of rambutan peel (Nephelium Lappaceum), was analyzed using the Kruskal Wallis test. This was done because the results of the prerequisite analysis showed that the data were not homogeneous and not normally distributed. The Kruskal Wallis test results show that the value $\chi 2$ count $=9,359$ with a significance value of $0.025<0.05$. From these results, the data 
concluded that there was an effect of the use of mordant on the color depth of the silk fabric dyed using rambutan peel extract (Nephelium Lappaceum).

\section{Conclusion}

The results of the color depth test have the highest value on the use of mordan tunjung with an R\% value of 11.94 for very dark criteria, then followed by mordan alum with a value of 47.15 and the lowest value on the use of calium oxide mordan with a value of 58.87 light criteria. There is an effect of the use of mordant on the coloration of the silk fabric dyed with rambutan peel extract.

\section{References}

[1] Clark M 2011 Handbook of Textile and Industrial Dyeing (Cambridge: Woodhead Publishing)

[2] Kusumastuti, Adhi and Rodia Syamwil. 2016. The Recycle of Batik Wax an Effort towards Environmental Friendly Process. International Journal of Inovative Reseach in Anvanced Engineering (IJIRAE) 3 48-51

[3] Martín J, Navas MJ, Jiménez-Moreno AM and Asuero AG 2015 Anthocyanin Pigments: Importance, Sample Preparation and Extraction (London: IntechOpen)

[4] Priyatno, D. 2010 Teknik Mudah dan Cepat Melakukan Analisis Data Penelitian dengan SPSS (Yogyakarta: Gava Media)

[5] Saxena S and Raja A S M 2014 Natural Dyes: Sources, Chemistry, Application and Sustainability Issues in Roadmap to Sustainable Textiles and Clothing: Eco-friendly Raw Materials, Technologies, and Processing Methods S.S. Muthu Editor (Singapore: Springer Singapore) p. 37-80

[6] Taofik, M., et al. 2010 Isolasi dan Identifikasi Senyawa Aktif Ekstrak Air Daun Paitan (Thitonia Diversifolia) sebagai Bahan Insektisida Botani untuk Pengendalian Hama Tungau Eriophydae. Alchemy, 2, 104-157

[7] Yazaki Y 2015 Wood Colors and their Coloring Matters: A Review Natural Product Communications 10 505-512 